\title{
Synthesis and Characterization of Group-6 Metal Carbonyl Complexes of Aroyl Hydrazone Derivatives
}

\author{
MOHD SALEEM, MOHITA SHARMA, SIMPY MAHAJAN, \\ H. N. SHEIKH* AND B. L. KALSOTRA \\ Department of Chemistry, \\ University of Jammu, Jammu-1800 06, India \\ hnsheikh@rediffmail.com
}

Received 22 February 2011; Revised 16 July 2011; Accepted 30 July 2011

\begin{abstract}
Carbonyl complexes of Chromium, molybdenum and tungsten of composition, $\left[\mathrm{M}(\mathrm{CO})_{4} \mathrm{~L}-\mathrm{L}\right]$, (where $\mathrm{M}=\mathrm{Cr}$, Mo or $\mathrm{W}$ and $\mathrm{L}-\mathrm{L}=$ benzoic acid[1-(Furan-2-yl)methylene]hydrazide (BFMH), benzoic acid[(thiophene-2yl)methylene]hydrazide (BTMH), benzoic acid[1-(thiophene-2-yl)ethylidene] hydrazide (BTEH), benzoic acid (phenylmethylene)hydrazide (BPMH) and benzoic acid[1-(anisol-3-yl)methylene] hydrazide (BAMH) are reported. These have been prepared by refluxing metal carbonyls and the ligands in 1:1molar ratio. The complexes were characterized by elemental analysis, IR spectra, UV-vis spectra, ${ }^{1} \mathrm{H}$ NMR, TGA/DTA, conductivity and magnetic susceptibility measurements. The IR bands suggest that in all the complexes the ligands behave as neutral bidentate chelating type coordinating metal through carbonyl oxygen and azomethine nitrogen. The $\mathrm{CO}$ force constants and $\mathrm{CO}-\mathrm{CO}$ interaction constants for these derivatives have been calculated using CottonKraihanzel secular equations, which indicate poor $\pi$-bonding ability of the coordinated ligands.
\end{abstract}

Keywords: Carbonyl complexes, Cotton-Kraihanzel secular equations, Bidentate ligands, Molybdenum, Tungsten, Schiff bases.

\section{Introduction}

The chemistry of metal carbonyls has been of considerable interest for several decades mainly due to structural aspects and reactivity of these compounds in respect to several classes of organic ligands, and also by their applications in catalysis and in electronic devices based on non-linear optical effects ${ }^{1-4}$. Transition metal carbonyl derivatives are intermediates in homogeneous catalytic reactions such as carbonylation, hydrogenation, hydroformylation and oxygen transfer ${ }^{5}$. They are common starting materials for the synthesis of other low- valent metal complexes, especially clusters. The carbonyl ligands can not only be substituted by a large number of other ligands (lewis bases, olefins, and arenes), but the remaining carbonyl groups stabilize the molecules against oxidation or thermal decomposition. Carbonyl groups are also useful probe for determining the electronic and 
molecular structure of organometallic species by spectroscopic methods ${ }^{6}$. Research on preparation, structures and applications of metal carbonyls and their derivatives has been intense for several decades. The first metal carbonyl, $\mathrm{Ni}(\mathrm{CO})_{4}$, was prepared by $\mathrm{A}$. Mond and coworkers ${ }^{7}$ in 1890 by the reaction of metallic nickel with carbon monoxide. It found application immediately and has been used for industrial preparation of pure nickel. Many other carbonyls were synthesized shortly thereafter ${ }^{8}$. Carbonyl complexes of group 6 which contain nitrogen and phosphorus ligands exhibit an interesting and varied chemistry ${ }^{9-11}$. Reports on 2, 2' - bipyridine (bipy) substituted tetracarbonyls and tricarbonyl phosphine complexes and their structural investigation emerged from literature many years ago ${ }^{12}$. $\mathrm{S}, \mathrm{N}$-ligated derivatives of hexacarbonyltungsten $(0), \quad\left[\mathrm{NEt}_{4}\right]\left[\mathrm{W}(\mathrm{CO})_{4} \mathrm{~L}-\mathrm{L}\right] \quad(\mathrm{L}-\mathrm{L}=$ 2-thiouracilate and 6-methyl-2thiouracilate] have been synthesized from reaction of photogenerated $\mathrm{W}(\mathrm{CO})_{5}$ (solvent) (solvent $=\mathrm{MeOH}$ or THF) and corresponding $\left[\mathrm{Et}_{4} \mathrm{~N}\right]\left[\right.$ thiouracilate $^{13}$. Novel orotic acid derivatives of tungsten carbonyl, $\left[\mathrm{Et}_{4} \mathrm{~N}\right]_{2}\left[\mathrm{~W}(\mathrm{CO})_{4}\right.$ (orotate) $],\left[\mathrm{Et}_{4} \mathrm{~N}\right]_{2}\left[\mathrm{~W}(\mathrm{CO})_{4}\right.$ (dihydroorotate)] [where orotate $=\left(\mathrm{C}_{5} \mathrm{H}_{2} \mathrm{O}_{4} \mathrm{~N}_{2}\right)^{2-}$, dihydroorotate $\left.=\left(\mathrm{C}_{5} \mathrm{H}_{4} \mathrm{O}_{4} \mathrm{~N}_{2}\right)^{2-}\right]$ have been reported and found to be O,Nligated complexes ${ }^{14,15}$. Chromium, manganese, cobalt, nickel and ruthenium carbonyl complexes with a wide variety of ligands having donor atom sets such as $\mathrm{N}_{2} \mathrm{O}_{2}, \mathrm{NO}_{2}$ and $\mathrm{N}_{4}$ around the metal ion have been used as catalysts for epoxidation reactions ${ }^{16-19}$. In the present study we have used ligands namely benzoic acid[1-(Furan-2-yl)methylene]hydrazide (BFMH), benzoic acid[(thiophene-2-yl)methylene]hydrazide (BTMH) , benzoic acid[1-(thiophene-2yl)ethylidene]hydrazide (BTEH) , benzoic acid (phenylmethylene)hydrazide (BPMH) and benzoic acid[1-(anisol-3-yl)methylene] hydrazide (BAMH) in the CO displacement reactions of $\mathrm{M}(\mathrm{CO})_{6}$ (where $\mathrm{M}=\mathrm{Cr}$, Mo and $\mathrm{W}$ ), yielding cis-disubstituted products, $\left[\mathrm{M}(\mathrm{CO})_{4} \mathrm{~L}-\mathrm{L}\right]$ (where $\mathrm{L}-\mathrm{L}=$ aroylhydrazone ligands). The structures of ligands are given below:

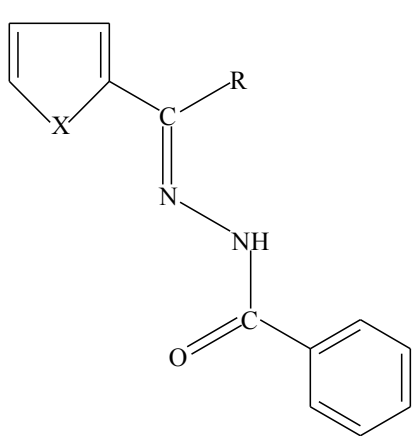

BFMH where $\mathrm{X}=\mathrm{O} \& \mathrm{R}=\mathrm{H}$

BTMH where $\mathrm{X}=\mathrm{S} \& \mathrm{R}=\mathrm{H}$

BTEH where $\mathrm{X}=\mathrm{S} \& \mathrm{R}=\mathrm{CH}_{3}$

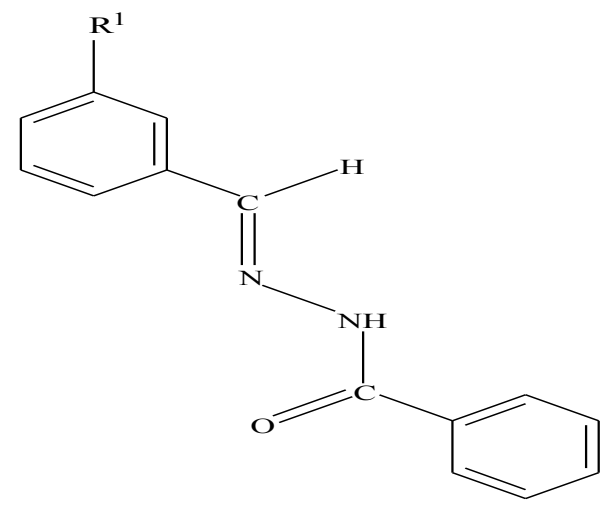

BPMH Where $\mathrm{R}^{1}=\mathrm{H}$

BAMH where $\mathrm{R}^{1}=\mathrm{OCH}_{3} \mathrm{BTEH}$

\section{Experimental}

Reagent grade furfuraldehyde (Himedia), thiophen-2-carboxaldehyde (Himedia), 2acetylthiophene (Himedia), benzaldehyde (Ranbaxy), anisaldehyde (Himedia), benzhydrazide (Fluka), THF (Ranbaxy), chromium hexacarbonyl (Aldrich), molybdenum hexacarbonyl (Aldrich), and tungsten hexacarbonyl (Aldrich) were used as received. The solvent used for the synthesis of ligands and their complexes were distilled before use. The ligands were prepared by the reported method ${ }^{20}$. 


\section{Methods and instruments}

Carbon, hydrogen, nitrogen and sulphur were analysed microanalytically using CHNS analyzer Leco make model-932. Metals analysis was done by gravimetric method ${ }^{21}$. Molar conductivity at room temperature in DMF $\left(10^{-3} \mathrm{M}\right)$ was measured using an Elicoconductvity Bridge, type CM82T and a conductivity cell with cell constant of 0.74 . Magnetic susceptibility of the complexes was recorded at room temperature using Gouy's balance and using $\mathrm{Hg}\left[\mathrm{Co}(\mathrm{NCS})_{4}\right]$ as a standard. IR spectra of complexes over the region $4000-400 \mathrm{~cm}^{-1}$ were recorded on a Perkin Elmer FTIR spectrophotometer using $\mathrm{KBr}$ disc. The electronic spectra of the complexes were recorded using a double beam UV-visible spectrophotometer type SL-164. Thermogravimetric analysis (DTA-DTG-TG) of complexes was recorded on Perkin Elmer (Pyris Diamond) thermoanalyser at the heating rate of $10^{\circ} \mathrm{C} / \mathrm{min}$ in the atmosphere of air.

\section{Preparation of complexes}

$\left[\mathrm{Cr}(\mathrm{CO})_{4} \mathrm{~L}-\mathrm{L}\right]$

$\mathrm{Cr}(\mathrm{CO})_{6}(0.659 \mathrm{~g}, 3 \mathrm{mmol})$ and the ligand $\left.(3 \mathrm{mmol}):\right)$ : benzoic acid[1-(Furan-2-yl) methylene]hydrazide (BFMH) (0.642 g), benzoic acid [(thiophene-2-yl)methylene] hydrazide (BTMH) (0.690 g), benzoic acid [1-(thiophene-2-yl) ethylidene] hydrazide (BTEH) (0.732 g), benzoic acid (phenylmethylene) hydrazide (BPMH) $(0.672 \mathrm{~g})$ and benzoic acid [1-(anisol-3-yl) methylene] hydrazide (BAMH) $(0.762 \mathrm{~g})]$ were refluxed in 50 $\mathrm{ml}$ of THF for about 7-8 h under dry conditions in an atmosphere of nitrogen. The yellow solution obtained in each case was allowed to cool and coloured, air stable solid was obtained by evaporating the solvent in vacuo. Unreacted materials were removed by washing the residue several times with n-hexane. The product was recrystallized in THF (Yield: 60-65\%). The reaction was repeated with 1:2, 1:3 molar ratios of hexacarbonyl chromium $(0)$ and corresponding ligand and same product was isolated in each case.

$\left[\mathrm{Mo}(\mathrm{CO})_{4} \mathrm{~L}-\mathrm{L}\right]$

$\mathrm{Mo}(\mathrm{CO})_{6}(264 \mathrm{mg}, 1.0 \mathrm{mmol})$ and the ligand ( $\left.1.0 \mathrm{mmol}\right)$ : benzoic acid[1-(Furan-2yl)methylene] hydrazide (BFMH) (0.214 g), benzoic acid [(thiophene-2-yl)methylene] hydrazide $(\mathrm{BTMH})(0.230 \mathrm{~g})$, benzoic acid [1-(thiophene-2-yl)ethylidene] hydrazide (BTEH) (0.244 g), benzoic acid (phenylmethylene) hydrazide (BPMH) $(0.224 \mathrm{~g})$ and benzoic acid[1-(anisol-3yl)methylene] hydrazide (BAMH) $(0.254 \mathrm{~g})]$ were dissolved in xylene $(30 \mathrm{ml})$. The solution was refluxed for 4-5 hours. After cooling to room temperature, the solvent was removed in vacuo and the residue was dissolved in chloroform: dichloromethane (5:2) and left to stand for two days for crystallization at room temperature. The solvent was decanted and the crystals were dried in vacuo (Yield: $70-80 \%$ ). The reaction was repeated with 1:2, 1:3 molar ratios of hexacarbonyl molybdenum $(0)$ and corresponding ligand and same product was isolated in each case.

$\left[\mathrm{W}(\mathrm{CO})_{4} L-L\right]$

$\mathrm{W}(\mathrm{CO})_{6}(1.05 \mathrm{~g}, 3 \mathrm{mmol})$ and the ligand (3 mmol): benzoic acid[1-(Furan-2-yl)methylene] hydrazide (BFMH) $(0.642 \mathrm{~g})$, benzoic acid[(thiophene-2-yl)methylene] hydrazide (BTMH) $(0.690 \mathrm{~g})$, benzoic acid[1-(thiophene-2-yl)ethylidene]hydrazide (BTEH) $(0.732 \mathrm{~g})$, benzoic acid (phenylmethylene)hydrazide (BPMH) $(0.672 \mathrm{~g})$ and benzoic acid[1-(anisol-3yl)methylene]hydrazide (BAMH) $(0.762 \mathrm{~g})$ ] were refluxed in $50 \mathrm{ml}$ of THF for about $7-8 \mathrm{~h}$ under dry conditions in an atmosphere of nitrogen. The yellow solution obtained in each case was allowed to cool and the yellow orange, air stable solid was obtained by evaporating the solvent in vacuo. Unreacted materials were removed by washing the residue several times with n-hexane. The product was recrystallized in THF (Yield: $70-80 \%$ ). The reaction 
was repeated with 1:2, 1:3 molar ratios of hexacarbonyl tungsten( $(0)$ and corresponding ligand and same product was isolated in each case.

\section{Results and Discussion}

The analytical and physical data (Table 1) showed that all complexes are mononuclear with general formula, $\left[\mathrm{M}(\mathrm{CO})_{4} \mathrm{~L}-\mathrm{L}\right]$ (where $\mathrm{L}-\mathrm{L}=$ benzoic acid [1-(Furan-2-yl) methylene] hydrazide (BFMH), benzoic acid [(thiophene-2-yl) methylene] hydrazide (BTMH), benzoic acid [1-(thiophene-2-yl)ethylidene] hydrazide (BTEH), benzoic acid (phenylmethylene) hydrazide (BPMH) and benzoic acid[1-(anisol-3-yl) methylene] hydrazide (BAMH) and M $=\mathrm{Cr}, \mathrm{Mo}$, and $\mathrm{W})$. All the complexes are coloured, stable in air and soluble in THF, DMSO and DMF. The complexes have characteristic melting points. Moreover, magnetic susceptibility measurement at $30{ }^{\circ} \mathrm{C}$ indicates the diamagnetic nature of complexes.

Table 1. Analytical data and some physical properties of the synthesized complexes cis$\left[\mathrm{M}(\mathrm{CO})_{4}(\mathrm{~L}-\mathrm{L})\right]$.

\begin{tabular}{|c|c|c|c|c|c|c|c|c|c|c|}
\hline \multirow[b]{2}{*}{$\begin{array}{l}\dot{0} \\
\dot{z}\end{array}$} & \multirow[b]{2}{*}{ Complex } & \multirow[b]{2}{*}{$\begin{array}{c}\text { Mol. wt. } \\
\text { g/mol }\end{array}$} & \multirow[b]{2}{*}{ Colour } & \multirow[b]{2}{*}{$\begin{array}{l}\text { M.P., } \\
{ }^{\mathrm{O}} \mathrm{C}\end{array}$} & \multicolumn{5}{|c|}{ Found (Calculated) } & \multirow{2}{*}{$\begin{array}{c}\text { Molar } \\
\text { conductivity } \\
\text { mho } \\
\mathrm{cm}^{2} \mathrm{~mol}^{-1}\end{array}$} \\
\hline & & & & & $\mathrm{C}$ & $\mathrm{H}$ & $\mathrm{N}$ & $\mathrm{S}$ & c & \\
\hline 1 & $\begin{array}{c}\mathrm{Cr}(\mathrm{CO})_{4} \\
\mathrm{BFMH}\end{array}$ & 434.21 & $\begin{array}{l}\text { Bright } \\
\text { Yellow }\end{array}$ & 110 & $\begin{array}{c}44.11 \\
(44.27)\end{array}$ & $\begin{array}{c}2.11 \\
(2.30)\end{array}$ & $\begin{array}{c}7.00 \\
(6.44)\end{array}$ & & $\begin{array}{c}11.48 \\
(11.97)\end{array}$ & 21 \\
\hline 2 & $\begin{array}{c}\mathrm{Cr}(\mathrm{CO})_{4} \\
\mathrm{BTMH}\end{array}$ & 450.21 & $\begin{array}{l}\text { Dark } \\
\text { Brown }\end{array}$ & 105 & $\begin{array}{c}43.11 \\
(42.70)\end{array}$ & $\begin{array}{c}2.44 \\
(2.22)\end{array}$ & $\begin{array}{c}6.30 \\
(6.21)\end{array}$ & $\begin{array}{c}7.14 \\
(7.12)\end{array}$ & $\begin{array}{c}11.44 \\
(11.54)\end{array}$ & 28 \\
\hline 3 & $\begin{array}{c}\mathrm{Cr}(\mathrm{CO})_{4} \\
\mathrm{BTEH}\end{array}$ & 464.30 & Brown & 123 & $\begin{array}{c}44.12 \\
(43.97)\end{array}$ & $\begin{array}{c}3.12 \\
(2.79)\end{array}$ & $\begin{array}{c}6.10 \\
(6.03)\end{array}$ & $\begin{array}{c}6.95 \\
(6.90)\end{array}$ & $\begin{array}{c}11.89 \\
(11.19)\end{array}$ & 18 \\
\hline 4 & $\begin{array}{c}\mathrm{Cr}(\mathrm{CO})_{4} \\
\mathrm{BPMH}\end{array}$ & 442.24 & $\begin{array}{l}\text { Light } \\
\text { Brown }\end{array}$ & 128 & $\begin{array}{c}49.23 \\
(48.88)\end{array}$ & $\begin{array}{c}2.92 \\
(2.71)\end{array}$ & $\begin{array}{c}6.41 \\
(6.33)\end{array}$ & & $\begin{array}{c}12.23 \\
(11.75)\end{array}$ & 28 \\
\hline 5 & $\begin{array}{c}\mathrm{Cr}(\mathrm{CO})_{4} \\
\mathrm{BAMH}\end{array}$ & 472.27 & $\begin{array}{l}\text { Light } \\
\text { Brown }\end{array}$ & 130 & $\begin{array}{c}48.82 \\
(48.31)\end{array}$ & $\begin{array}{c}3.26 \\
(3.16)\end{array}$ & $\begin{array}{c}6.00 \\
(5.92)\end{array}$ & & $\begin{array}{c}11.51 \\
(11.00)\end{array}$ & 30 \\
\hline 6 & $\begin{array}{c}\mathrm{Mo}(\mathrm{CO})_{4} \\
\mathrm{BFMH}\end{array}$ & 422.16 & Black & 230 & $\begin{array}{c}45.12 \\
(45.54)\end{array}$ & $\begin{array}{c}3.00 \\
(2.36)\end{array}$ & $\begin{array}{c}6.87 \\
(6.63)\end{array}$ & & $\begin{array}{c}21.89 \\
(22.72)\end{array}$ & 15 \\
\hline 7 & $\begin{array}{c}\mathrm{Mo}(\mathrm{CO})_{4} \\
\text { BTMH }\end{array}$ & 438.22 & $\begin{array}{l}\text { Dark } \\
\text { Brown }\end{array}$ & 240 & $\begin{array}{c}44.12 \\
(43.86)\end{array}$ & $\begin{array}{c}2.36 \\
(2.28)\end{array}$ & $\begin{array}{c}6.39 \\
(6.38)\end{array}$ & $\begin{array}{c}7.50 \\
(7.31)\end{array}$ & $\begin{array}{c}21.13 \\
(21.89)\end{array}$ & 18 \\
\hline 8 & $\begin{array}{c}\mathrm{Mo}(\mathrm{CO})_{4} \\
\mathrm{BTEH}\end{array}$ & 452.25 & $\begin{array}{c}\text { Dark } \\
\text { Brown }\end{array}$ & 245 & $\begin{array}{c}45.12 \\
(45.14)\end{array}$ & $\begin{array}{c}3.25 \\
(3.05)\end{array}$ & $\begin{array}{c}6.22 \\
(6.19)\end{array}$ & $\begin{array}{c}7.12 \\
(7.07)\end{array}$ & $\begin{array}{c}21.10 \\
(21.21)\end{array}$ & 34 \\
\hline 9 & $\begin{array}{c}\mathrm{Mo}(\mathrm{CO})_{4} \\
\mathrm{BPMH}\end{array}$ & 432.19 & Black & 246 & $\begin{array}{c}50.87 \\
(50.01)\end{array}$ & $\begin{array}{c}2.82 \\
(2.77)\end{array}$ & $\begin{array}{c}6.60 \\
(6.47)\end{array}$ & & $\begin{array}{c}21.63 \\
(22.19)\end{array}$ & 29 \\
\hline 10 & $\begin{array}{c}\mathrm{Mo}(\mathrm{CO})_{4} \\
\mathrm{BAMH}\end{array}$ & 462.22 & Black & 253 & $\begin{array}{c}50.11 \\
(49.36)\end{array}$ & $\begin{array}{c}3.30 \\
(3.24)\end{array}$ & $\begin{array}{c}5.25 \\
(5.19)\end{array}$ & & $\begin{array}{c}20.12 \\
(20.75)\end{array}$ & 29 \\
\hline 11 & $\begin{array}{l}\mathrm{W}(\mathrm{CO})_{4} \\
\mathrm{BFMH}\end{array}$ & 509.92 & Yellow & 149 & $\begin{array}{c}37.58 \\
(37.70)\end{array}$ & $\begin{array}{c}2.01 \\
(1.96)\end{array}$ & $\begin{array}{c}6.00 \\
(5.94)\end{array}$ & …..... & $\begin{array}{c}35.99 \\
(36.08)\end{array}$ & 20 \\
\hline 12 & $\begin{array}{l}\mathrm{W}(\mathrm{CO})_{4} \\
\mathrm{BTMH}\end{array}$ & 526.02 & $\begin{array}{l}\text { Bright } \\
\text { Yellow }\end{array}$ & 140 & $\begin{array}{c}36.99 \\
(36.54)\end{array}$ & $\begin{array}{c}2.01 \\
(1.90)\end{array}$ & $\begin{array}{c}5.57 \\
(5.34)\end{array}$ & $\begin{array}{c}6.10 \\
(6.09)\end{array}$ & $\begin{array}{c}33.95 \\
(34.94)\end{array}$ & 28 \\
\hline 13 & $\begin{array}{c}\mathrm{W}(\mathrm{CO})_{4} \\
\mathrm{BTEH}\end{array}$ & 539.05 & Yellow & 152 & $\begin{array}{c}37.89 \\
(37.87)\end{array}$ & $\begin{array}{c}2.24 \\
(2.41)\end{array}$ & $\begin{array}{c}5.37 \\
(5.19)\end{array}$ & $\begin{array}{c}6.01 \\
(5.94)\end{array}$ & $\begin{array}{c}33.12 \\
(34.10)\end{array}$ & 22 \\
\hline 14 & $\begin{array}{c}\mathrm{W}(\mathrm{CO})_{4} \mathrm{~B} \\
\mathrm{PMH}\end{array}$ & 519.99 & $\begin{array}{l}\text { Light } \\
\text { yellow }\end{array}$ & 158 & $\begin{array}{c}41.82 \\
(41.57)\end{array}$ & $\begin{array}{c}2.66 \\
(2.30)\end{array}$ & $\begin{array}{c}5.18 \\
(5.38)\end{array}$ & .......... & $\begin{array}{c}35.01 \\
(35.35)\end{array}$ & 15 \\
\hline 15 & $\begin{array}{c}\mathrm{W}(\mathrm{CO})_{4} \mathrm{~B} \\
\mathrm{AMH}\end{array}$ & 550.02 & $\begin{array}{l}\text { Light } \\
\text { Yellow }\end{array}$ & 160 & $\begin{array}{c}42.01 \\
(41.48) \\
\end{array}$ & $\begin{array}{c}2.87 \\
(2.72) \\
\end{array}$ & $\begin{array}{c}5.11 \\
(5.09)\end{array}$ & & $\begin{array}{c}33.14 \\
(33.42)\end{array}$ & 21 \\
\hline
\end{tabular}




\section{Conductance measurement}

The molar conductivity (measured in $10^{-3} \mathrm{M}$ DMF solution) of these complexes is in the range of 15-34 mho cm $\mathrm{mol}^{-1}$ which is much less than the value of 70-160 mho cm $\mathrm{mol}^{-1}$ for 1:1 electrolyte in this solvent. Thus, these complexes are undissociated which indicates the non-electrolytic nature of these complexes.

\section{Infrared spectra}

The CO force constants and CO-CO interaction constants for these derivatives have been calculated using Cotton-Kraihanzel secular equations ${ }^{22}$.

$$
\begin{aligned}
& 2 \mathrm{~A} 1\left|\begin{array}{lr}
\mu(\mathrm{k} 2+2 \mathrm{ki})-2 \mu \mathrm{ki} \\
2 \mu \mathrm{ki} & \mu(\mathrm{k} 1+\mathrm{ki})-\lambda
\end{array}\right|=0 \\
& \mathrm{~B}_{1} \lambda=\mu\left(\mathrm{k}_{2}-2 \mathrm{k}_{\mathrm{i}}\right) \\
& \mathrm{B}_{2} \lambda=\mu\left(\mathrm{k}_{1}-\mathrm{k}_{\mathrm{i}}\right)
\end{aligned}
$$

In these equations, $\mathrm{k}_{1}=$ stretching force constant for $\mathrm{CO}$ groups trans to ligands, $\mathrm{k}_{2}=$ stretching force constant for $\mathrm{CO}$ groups cis to ligands, $\mathrm{k}_{\mathrm{i}}=\mathrm{CO}-\mathrm{CO}$ interaction force constant, $\mu=$ reciprocal of reduced mass of $\mathrm{CO}(0.14583)$ and $\mathrm{A}=\left(5.8890 \times 10^{-2} v^{2}\right)$ where $v=$ frequency in $\mathrm{cm}^{-1}$ and the force constants are in dynes $\mathrm{cm}^{-1}$.

All the complexes show four CO stretching bands in the infra red region 2075-1825 $\mathrm{cm}^{-1}$ due to $2 \mathrm{~A}_{1}+\mathrm{B}_{1}+\mathrm{B}_{2}$ modes as expected for $\mathrm{C}_{2 \mathrm{v}}$ symmetry and in agreement with their cisconfiguration. $^{22-25}$ The frequencies for the complexes of unsymmetrical ligands are assigned as follows. The higher frequency $\mathrm{A}_{1}$ and $\mathrm{B}_{1}$ bands are assigned to trans- carbonyl ligands, while the lower frequency $\mathrm{A}_{1}$ and $\mathrm{B}_{2}$ bands are assigned to cis-carbonyl ligands.

The values of $k_{1}, k_{2}$ and $k_{i}$ for tungsten complexes were found in the ranges 14.0914.44, 15.87-16.08 and 0.23-0.25 mdynes/ $\mathrm{A}^{\mathrm{O}}$ respectively, the values of $\mathrm{k}_{1}, \mathrm{k}_{2}$ and $\mathrm{k}_{\mathrm{i}}$ for molybdenum complexes were found in the ranges $13.75-13.96,15.69-16.03$ and $0.26-0.32$ mdynes $/ \mathrm{A}^{\mathrm{O}}$ respectively and the values of $\mathrm{k}_{1}, \mathrm{k}_{2}$ and $\mathrm{k}_{\mathrm{i}}$ for chromium complexes were found in the ranges 13.81-14.00, 15.59-15.80 and 0.20-0.25 mdynes $/ \mathrm{A}^{\mathrm{O}}$ respectively, which confirm the validity of vibrational mode assignments. The values of $\mathrm{CO}$ stretching force constants in the complexes are lower than that for $\mathrm{W}(\mathrm{CO})_{6}\left(16.41\right.$ mdynes $\left./ \mathrm{A}^{\mathrm{O}}\right), \mathrm{Mo}(\mathrm{CO})_{6}$ $\left(16.52\right.$ mdynes $\left./ \mathrm{A}^{\mathrm{O}}\right)$ and $\mathrm{Cr}(\mathrm{CO})_{6}\left(16.49 \mathrm{mdynes} / \mathrm{A}^{\mathrm{O}}\right)$ indicating the replacement of two $\mathrm{CO}$ groups by the ligand (L-L) and poor pi-bonding ability of the ligands used ${ }^{26,27}$. These values are close to the values of force constants deduced for other nitrogen containing cisdisubstituted group 6 metal carbonyls ${ }^{28,29}$.

Moreover, the IR bands appearing in the spectra of the free ligands (aroylhydrazone) at ca. 1660 and $1640 \mathrm{~cm}^{-1}$ are attributed to amide $v(\mathrm{C}=\mathrm{O})$ and $v(\mathrm{C}=\mathrm{N})$ modes respectively ${ }^{30}$. The spectra of free ligands exhibit $v(\mathrm{~N}-\mathrm{H})$ stretching band at $c a .3250$ and $v(\mathrm{C}=\mathrm{N})$ bands $c a .1640 \mathrm{~cm}^{-1}$ indicating that ligands exist in keto form. The presence of $v(\mathrm{~N}-\mathrm{H})$ bands in the spectra of the complexes suggest that all the ligands remain protonated on complexation to metal. The amide bands $v(\mathrm{C}=\mathrm{O})$ and $v(\mathrm{C}=\mathrm{N})$ shift to lower frequencies (Table 2) in the spectra of complexes suggesting the involvement of carbonyl oxygen and azomethine nitrogen in coordination to metal ${ }^{31}$. Thus, these observations suggest that the ligands behave as neutral bidentate chelating type coordinating metal through carbonyl oxygen and azomethine nitrogen. The Ir spectra of two representative complexes namely $\mathrm{Mo}(\mathrm{CO})_{4} \mathrm{BFMH}$ and $\mathrm{Mo}(\mathrm{CO})_{4} \mathrm{BTMH}$ are given in Figure 1 and 2 respectively. 
Table 2 IR spectral data $\left(\mathrm{cm}^{-1}\right)$ and CO force constants of cis-[M(CO) $\left.(\mathrm{L}-\mathrm{L})\right]$ Complexes.

\begin{tabular}{|c|c|c|c|c|c|c|c|c|c|c|c|}
\hline \multirow{2}{*}{$\begin{array}{l}\dot{z} \\
\dot{z}\end{array}$} & \multirow[t]{2}{*}{ Complex } & \multirow{2}{*}{$\begin{array}{c}\mathrm{N} \\
(\mathrm{C}=\mathrm{O})(\end{array}$} & \multirow{2}{*}{$\begin{array}{c}\mathrm{N} \\
(\mathrm{C}=\mathrm{N})\end{array}$} & \multirow[t]{2}{*}{$\mathrm{N}$} & \multicolumn{4}{|c|}{$v(\mathrm{C}=\mathrm{O})$} & \multicolumn{3}{|c|}{$\begin{array}{l}\text { Force constant } \\
\left(\text { mdynes } \mathrm{A}^{\mathrm{o}-1}\right)\end{array}$} \\
\hline & & & & & $\mathrm{A}_{1}$ & $\mathrm{~B}_{1}$ & $\mathrm{~A}_{1}$ & $\mathrm{~B}_{2}$ cis & $\mathrm{k}_{1}$ & $\mathrm{~K}_{2}$ & $\mathrm{~K}_{3}$ \\
\hline 1 & $\mathrm{Cr}(\mathrm{CO})_{4} \mathrm{BFMH}$ & 1627 & 1598 & 3242 & 2026 & 1947 & 19025 & 1835 & 13.81 & 15.75 & 0.22 \\
\hline 2 & $\mathrm{Cr}(\mathrm{CO})_{4} \mathrm{BTMH}$ & 1627 & 1597 & 3244 & 2023 & 1940 & 1913 & 1845 & 14.00 & 15.59 & 0.25 \\
\hline 3 & $\mathrm{Cr}(\mathrm{CO})_{4} \mathrm{BTEH}$ & 1631 & 1594 & 3258 & 2033 & 1939 & 1904 & 1835 & 13.8 & 15. & 0.25 \\
\hline 4 & $\mathrm{Cr}(\mathrm{CO})_{4} \mathrm{BPMH}$ & 1628 & 1590 & 3255 & 2038 & 1947 & 1915 & 1844 & 120 & 10 & 0.20 \\
\hline 5 & $\mathrm{Cr}(\mathrm{CO})_{4} \mathrm{BAMH}$ & 1629 & 1601 & 3273 & 2030 & 1941 & 1910 & 1845 & 13. & 15. & 0.24 \\
\hline 6 & $\mathrm{Mo}(\mathrm{CO})_{4} \mathrm{BFMH}$ & 1631 & 1594 & 3242 & 2050 & 1955 & 1907 & 1853 & 1385 & 1505 & 0.26 \\
\hline 7 & $\mathrm{Mo}(\mathrm{CO})_{4} \mathrm{BTMH}$ & 1631 & 1588 & 3258 & 2075 & 1950 & 1905 & 1840 & 13. & 15. & 0.29 \\
\hline 8 & $\mathrm{Mo}(\mathrm{CO})_{4} \mathrm{BTEH}$ & 1631 & 1594 & 3258 & 2056 & 1932 & 1910 & 1825 & 1276 & 1560 & 0.32 \\
\hline 9 & $\mathrm{Mo}(\mathrm{CO})_{4} \mathrm{BPMH}$ & 1628 & 1590 & 3256 & 2065 & 1957 & 1907 & 13.84 & 13.8 & 16.0 & 0.28 \\
\hline 10 & $\mathrm{Mo}(\mathrm{CO})_{4} \mathrm{BAMH}$ & 1622 & 1604 & 3273 & 2050 & 1943 & 1908 & 1826 & 15.13 & 10.02 & 0.26 \\
\hline 11 & $\mathrm{~W}(\mathrm{CO})_{4} \mathrm{BFMH}$ & 1648 & 1605 & 3322 & 2050 & 1964 & 1915 & 1859 & 14.2 & 160 & 0.25 \\
\hline 12 & $\mathrm{~W}(\mathrm{CO})_{4} \mathrm{BTMH}$ & 1648 & 1599 & 3258 & 2054 & 1958 & 1922 & 1872 & 14.38 & 15. & 0.23 \\
\hline 13 & $\mathrm{~W}(\mathrm{CO})_{4} \mathrm{BTEH}$ & 1640 & 1594 & 3258 & 2075 & 1962 & 1930 & 1875 & 14.44 & 1604 & 0.25 \\
\hline 14 & $\mathrm{~W}(\mathrm{CO})_{4} \mathrm{BPMH}$ & 1634 & 1610 & 3235 & 2045 & 1952 & 1925 & 1859 & 14.19 & 15.87 & 0.24 \\
\hline 15 & $\mathrm{~W}(\mathrm{CO})_{4} \mathrm{BAMH}$ & 1642 & 1604 & 3260 & 2045 & 1964 & 1933 & 1852 & 14.09 & 16.05 & 0.24 \\
\hline
\end{tabular}

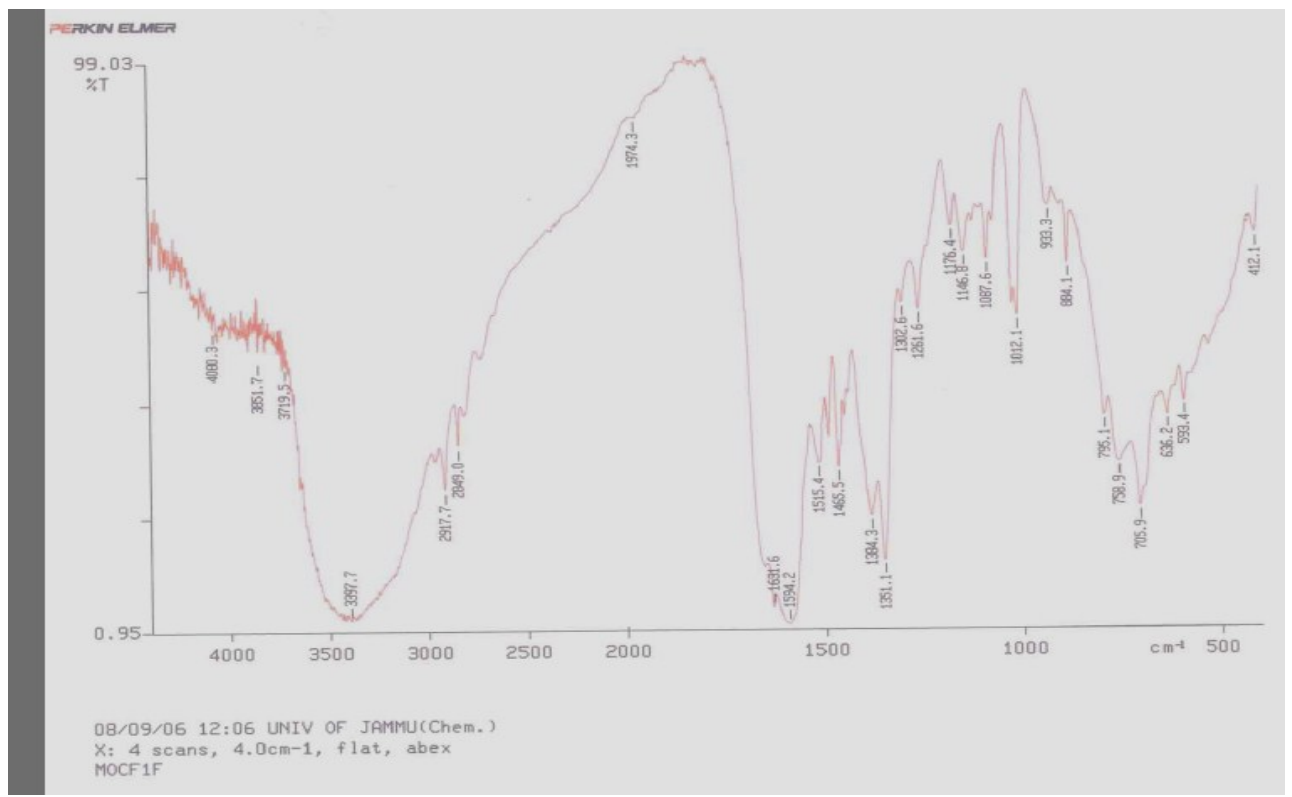

Figure 1. IR spectrum of $\left[\mathrm{Mo}(\mathrm{CO})_{4} \mathrm{BFMH}\right]$. 


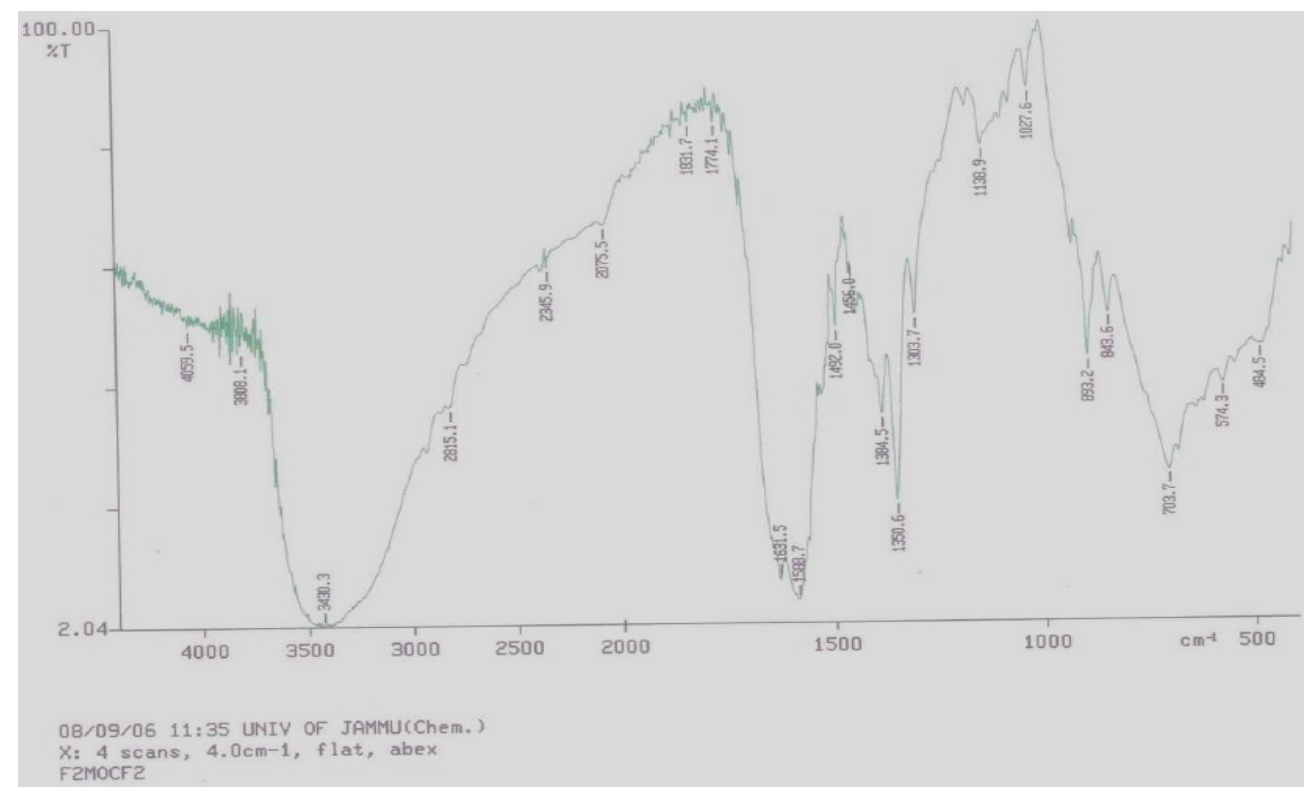

Figure 2. IR spectrum of $\left[\mathrm{Mo}(\mathrm{CO})_{4} \mathrm{BTMH}\right]$.

\section{Electronic spectra}

Electronic spectra of mixed ligand carbonyl derivatives of the type $c i s-\mathrm{M}(\mathrm{CO})_{4} \mathrm{~L}-\mathrm{L}(\mathrm{M}=\mathrm{Cr}, \mathrm{Mo}$ and $\mathrm{W}$ and $\mathrm{L}-\mathrm{L}=$ a bidentate nitrogen ligand) have been extensively studied by Stufkens and collaborators $^{32,33}$.

The complexes under study exhibit three sharp spectral peaks (Table 3) in the region of 325$440 \mathrm{~nm}$. These may be attributed to $\mathrm{d}-\pi^{*} \mathrm{CO}$ transitions. A peak of low intensity in the region of 475- $510 \mathrm{~nm}$ is also observed in these complexes which may be assigned to d-d transition.

Table 3. Electronic spectral data of cis- $\left[\mathrm{M}(\mathrm{CO})_{4}(\mathrm{~L}-\mathrm{L})\right]$ Complexes.

\begin{tabular}{|c|c|c|c|}
\hline S.No. & Complex & $\begin{array}{c}\lambda_{\max }\left(\mathrm{d}-\pi^{*} \mathrm{CO}\right. \\
\text { Transition }) \\
\end{array}$ & $\lambda_{\max }(\mathrm{d}-\mathrm{d}$ Transition $)$ \\
\hline 1 & {$\left[\mathrm{Cr}(\mathrm{CO})_{4} \mathrm{BFMH}\right]$} & $325,367,393$ & 498 \\
\hline 2 & {$\left[\mathrm{Cr}(\mathrm{CO})_{4} \mathrm{BTMH}\right]$} & $349,377,403$ & 478 \\
\hline 3 & {$\left[\mathrm{Cr}(\mathrm{CO})_{4} \mathrm{BTEH}\right]$} & $336,380,393$ & 510 \\
\hline 4 & {$\left[\mathrm{Cr}(\mathrm{CO})_{4} \mathrm{BPMH}\right]$} & $345,381,392$ & 501 \\
\hline 5 & {$\left[\mathrm{Cr}(\mathrm{CO})_{4} \mathrm{BAMH}\right]$} & $352,378,405$ & 499 \\
\hline 6 & {$\left[\mathrm{Mo}(\mathrm{CO})_{4} \mathrm{BFMH}\right]$} & $328,373,399$ & 484 \\
\hline 7 & {$\left[\mathrm{Mo}(\mathrm{CO})_{4} \mathrm{BTMH}\right]$} & $325,368,440$ & 510 \\
\hline 8 & {$\left[\mathrm{Mo}(\mathrm{CO})_{4} \mathrm{BTEH}\right]$} & $339,364,413$ & 476 \\
\hline 9 & {$\left[\mathrm{Mo}(\mathrm{CO})_{4} \mathrm{BPMH}\right]$} & $338,371,418$ & 490 \\
\hline 10 & {$\left[\mathrm{Mo}(\mathrm{CO})_{4} \mathrm{BAMH}\right]$} & $348,382,419$ & 497 \\
\hline 11 & {$\left[\mathrm{~W}(\mathrm{CO})_{4} \mathrm{BFMH}\right]$} & $346,387,329$ & 479 \\
\hline 12 & {$\left[\mathrm{~W}(\mathrm{CO})_{4} \mathrm{BTMH}\right]$} & $357,387,418$ & 497 \\
\hline 13 & {$\left[\mathrm{~W}(\mathrm{CO})_{4} \mathrm{BTEH}\right]$} & $353,388,412$ & 478 \\
\hline 14 & {$\left[\mathrm{~W}(\mathrm{CO})_{4} \mathrm{BPMH}\right]$} & $362,390,422$ & 493 \\
\hline 15 & {$\left[\mathrm{~W}(\mathrm{CO})_{4} \mathrm{BAMH}\right]$} & $332,390,408$ & 475 \\
\hline
\end{tabular}




\section{${ }^{l} H N M R$}

The ${ }^{1} \mathrm{H}$ NMR spectra of ligands in DMSO show low field signals at 11.8-11.4 ppm for the imino proton confirming the existence of ligands in keto form. The $\mathrm{CH}=\mathrm{N}$ peak is observed at $8.40-8.60 \mathrm{ppm}$ and signal due to aromatic protons which occurs as multiplets appears between $\delta 6.4-7.8 \mathrm{ppm}$. The resonance signal due to $\mathrm{CH}_{3}$ protons present in BTEH ligand occurs at $2.43 \mathrm{ppm}$. The spectra of all complexes show low field signals for imino proton at nearly same $\delta$ value as that of corresponding free ligands. Moreover, $\mathrm{CH}=\mathrm{N}$ peak in complexes is shifted towards higher delta value (8.78-9.12) due to deshielding because of bonding of azomethine nitrogen with metal. The ${ }^{1} \mathrm{H}$ NMR spectrum of a representative complex, $\mathrm{W}(\mathrm{CO})_{4} \mathrm{BTMH}$ is given in Figure 3.

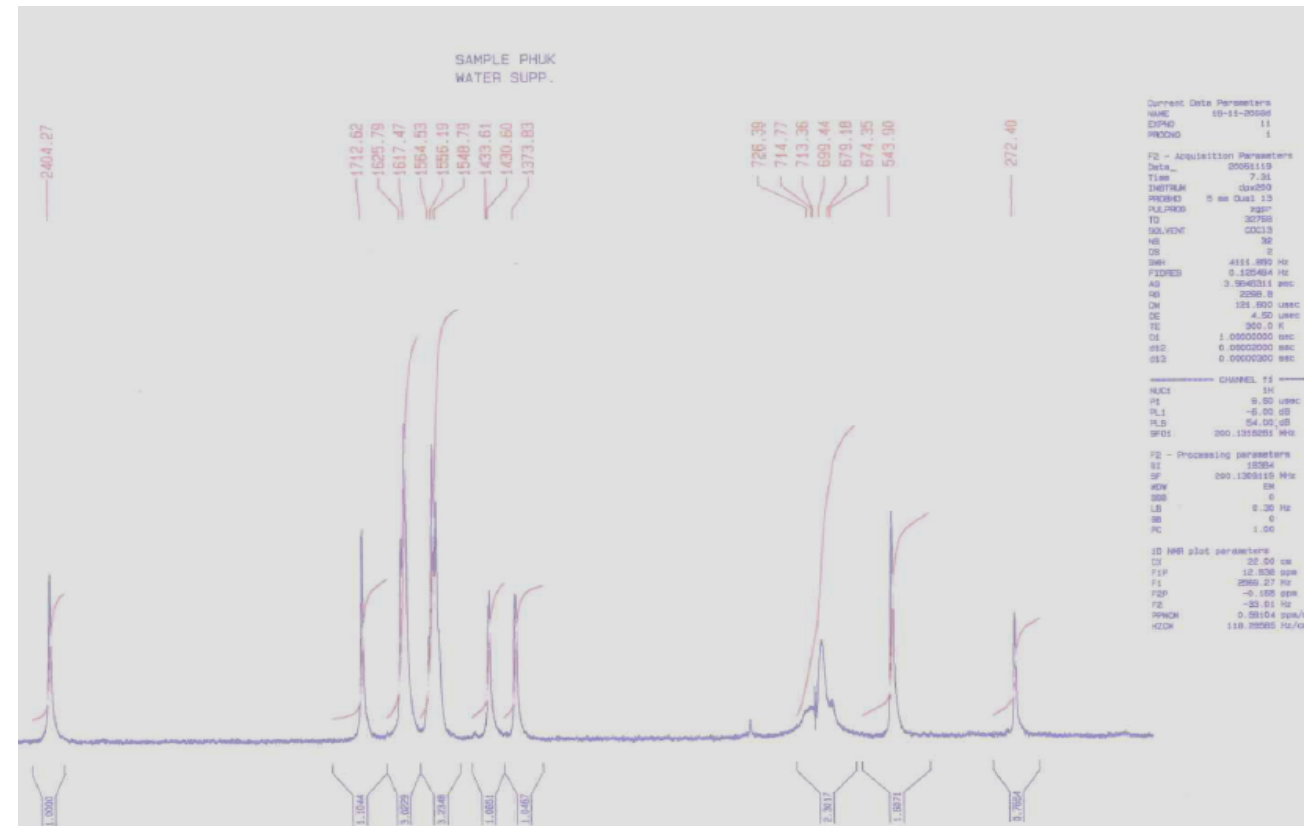

Figure 3. ${ }^{1} \mathrm{H}$ NMR spectrum of a representative complex [W(CO) $\left.{ }_{4} \mathrm{BTMH}\right]$.

\section{TGA/DTA studies}

The Thermogravimetric curves of the compounds were recorded in the temperature range of $25-800{ }^{0} \mathrm{C}$ in the atmosphere of air. The TGA curves of the representative complexes $\left[\mathrm{W}(\mathrm{CO})_{4} \mathrm{BFMH}\right]$ and $\left[\mathrm{Mo}(\mathrm{CO})_{4} \mathrm{BFMH}\right]$ indicate a continuous weight loss till a metal oxide is formed.

\section{TGA/DTA of $\left[\mathrm{W}(\mathrm{CO})_{4} \mathrm{BFMH}\right]$}

The TG curve of the complex, $\left[\mathrm{W}(\mathrm{CO})_{4} \mathrm{BFMH}\right]$ (Figure 4) shows a sharp weight loss starting from $100^{\circ} \mathrm{C}$ upto $300^{\circ} \mathrm{C}$ probably due to the loss of carbonyl groups. Thereafter a gradual but continuous weight loss takes place upto $600^{\circ} \mathrm{C}$ probably due to the decomposition and loss of BFMH ligand. Further heating upto $800^{\circ} \mathrm{C}$ does not show any weight loss indicating the formation of stable metal oxide, $\mathrm{WO}_{2}$ (Calculated weight $=$ $42.32 \%$ and observed weight $=42.42 \%$ ). DTA curve also shows two exothermic peaks at $300^{\circ} \mathrm{C}$ and $600^{\circ} \mathrm{C}$ indicating decomposition of complex at $300^{\circ} \mathrm{C}$ and $600^{\circ} \mathrm{C}$ and oxidation of $\mathrm{W}$ to $\mathrm{WO}_{2}$ and its crystallization. 


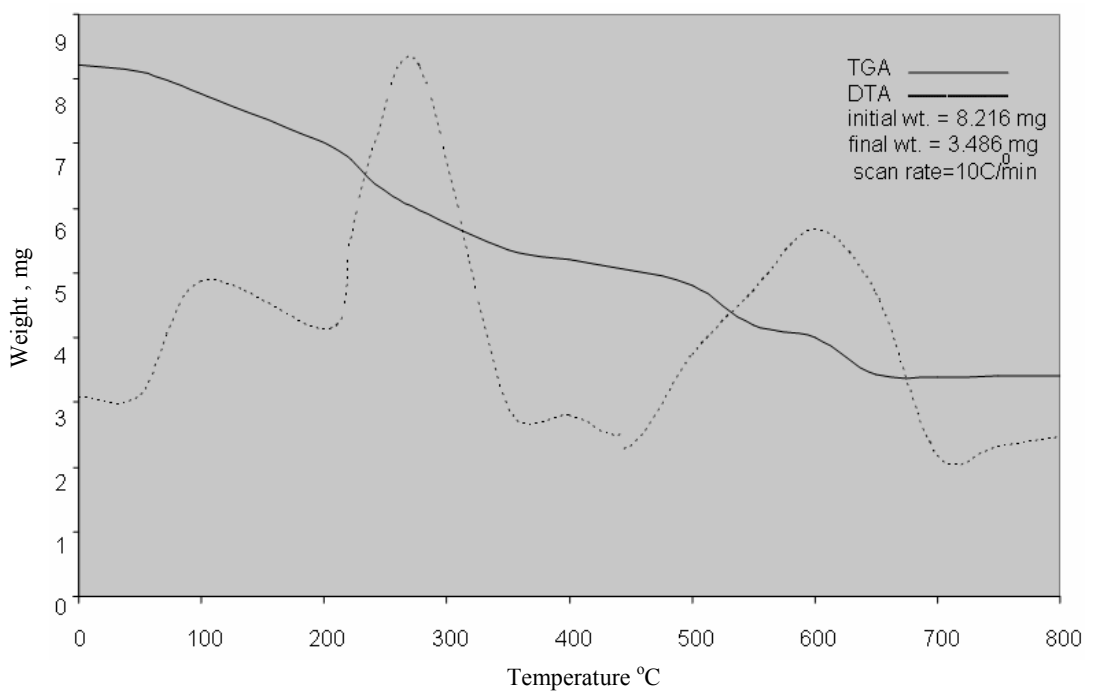

Figure 4. TGA/DTA Studies of $\left[\mathrm{W}(\mathrm{CO})_{4} \mathrm{BFMH}\right]$.

\section{TGA/DTA of $\left[\mathrm{Mo}(\mathrm{CO})_{4} \mathrm{BFMH}\right]$}

The TG curve of the complex, $\left[\mathrm{Mo}(\mathrm{CO})_{4} \mathrm{BFMH}\right]$ (Figure 5) shows a sharp weight loss starting from $200{ }^{\circ} \mathrm{C}$ up to $300{ }^{\circ} \mathrm{C}$ probably due to the loss of carbonyl groups. Thereafter a gradual but continuous weight loss takes place upto $600^{\circ} \mathrm{C}$ probably due to the decomposition and loss of BFMH ligand. Further heating upto $800{ }^{\circ} \mathrm{C}$ donot show any weight loss indicating the formation of stable metal oxide, $\mathrm{MoO}_{2}($ Calculated weight $=$ $30.30 \%$ and observed weight $=30.20 \%$ ). DTA curve also shows two exothermic peaks at $300{ }^{\circ} \mathrm{C}$ and $600{ }^{\circ} \mathrm{C}$ indicating decomposition of complex at $300{ }^{\circ} \mathrm{C}$ and $600{ }^{\circ} \mathrm{C}$ and oxidation of $\mathrm{Mo}$ to $\mathrm{MoO}_{2}$ and its crystallization.

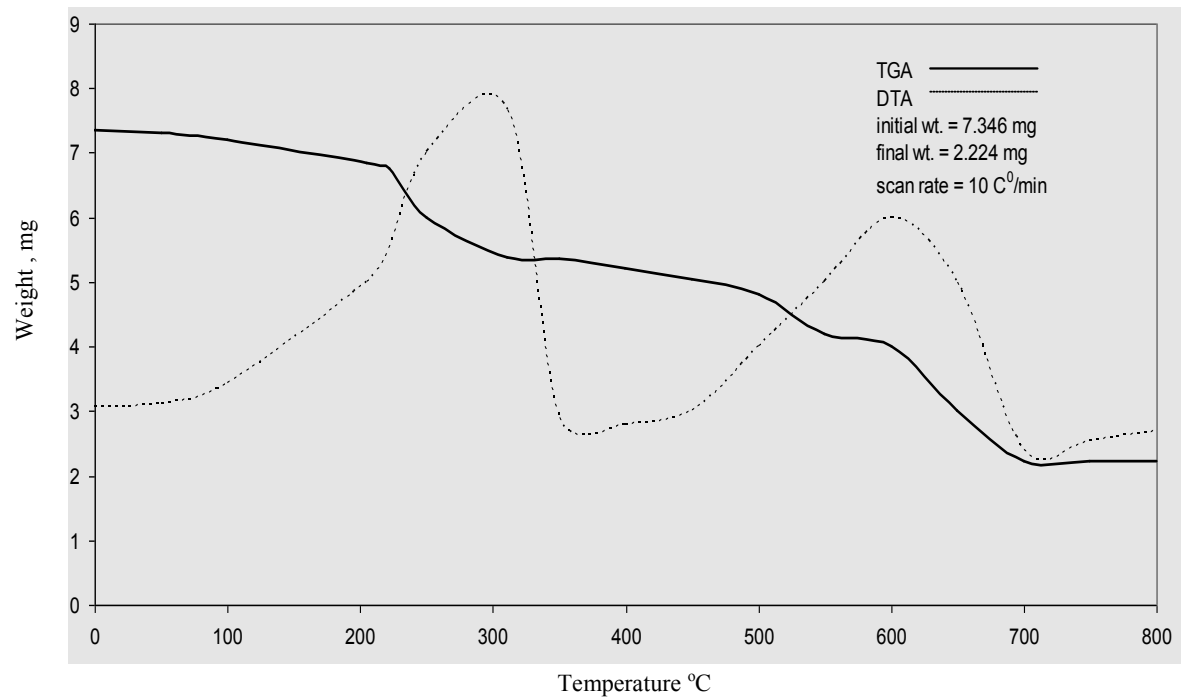

Figure 5. TGA/DTA studies of $\left[\mathrm{Mo}(\mathrm{CO})_{4} \mathrm{BFMH}\right]$. 


\section{Conclusion}

Based on physicochemical and spectral studies, it is proposed that these complexes are mononuclear with composition, $\left[\mathrm{M}(\mathrm{CO})_{4} \mathrm{~L}-\mathrm{L}\right]$ having cis configuration, where $\mathrm{L}-\mathrm{L}=$ benzoic acid[1-(Furan-2-yl)methylene]hydrazide (BFMH), benzoic acid[(thiophene-2-yl)methylene] hydrazide (BTMH), benzoic acid[1-(thiophene-2-yl)ethylidene]hydrazide (BTEH), benzoic acid (phenylmethylene) hydrazide (BPMH) and benzoic acid[1-(anisol-3-yl)methylene] hydrazide $(\mathrm{BAMH})$ and $\mathrm{M}=\mathrm{Cr}$, Mo and $\mathrm{W})$. IR spectral studies reveal that the ligands (L-L) behave as bidentate coordinating metal through carbonyl oxygen and azomethine nitrogen of the corresponding ligands. ${ }^{1} \mathrm{H}$ NMR also reveals the coordination of ligand to metal through carbonyl oxygen and azomethine nitrogen. The electronic spectra of complexes show peaks responsible for $\mathrm{d}$-d transition. Molar conductance of complexes indicates that these complexes behave as non-electrolytes and are undissociated in solutions. The Thermogravimetric curves of the compounds were recorded in the temperature range of $25-800{ }^{0} \mathrm{C}$ in the atmosphere of air. The TGA curves of the two representative complexes indicate a continuous weight loss till a metal oxide is formed. On the basis of above facts, following structure is proposed for these complexes.

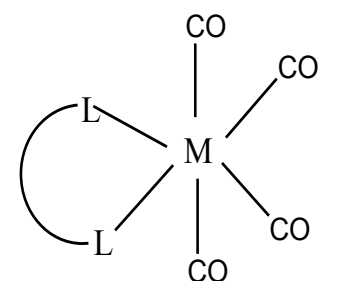

$\mathrm{M}=\mathrm{Cr}$, Mo and $\mathrm{W}, \mathrm{L}-\mathrm{L}=\mathrm{BFMH}, \mathrm{BTMH}, \mathrm{BTEH}, \mathrm{BPMH}$ and BAMH

\section{References}

1. Casagrande Jr O L, Tomita K and Vollet D R, Polyhedron, 1996, 15, 4179.

2. Datta P and Sinha C, Polyhedron, 2007, 26, 2433.

3. Ward M D, Coord Chem Rev., 1992, 115, 1.

4. Datta P, Sardar D, Mulkhopadhayay A P, Lopez-Torres E, Pastor C J and Sinha C, J Organometal Chem., 2011, 696, 488.

5. Collman J P and Hegedus L S, Principles and Applications of Organotransition Metal Chemistry (University Science Books, Mill Valley, California, 1980).

6. Elschenbroich $\mathrm{C}$ and Salzer A, Organometallics A Concise Introduction, VCH Publishers, 1992.

7. Mond L, Langer C and Quincke F, J Chem Soc., 1890, 57, 749.

8. Wender I and Pino P, Organic Synthesis via Metal Carbonyls, Vol. 1 Interscience, New York, 1968.

9. Darensbourg D J, Klausmeyer K K and Reibenspies J H, Inorg Chem., 1996, 35, 1535.

10. Mathur P, Sekar P, Rheingold A Land Liable-Sands L M, Organomet., 1997, 16, 142.

11. Bhadbhade M M, Das A, Jeffery J C, Badiola J A N and Ward M D, J Chem soc Dalton Trans., 1995, 2769.

12. Hors T S A, Inorg Chim Acta, 1987, 128, L3.

13. Darensbourg D J, Frost B J, Kovacs A D and Reibenspies J H, Inorg Chem., 1999, 38, 4715.

14. Darensbourg D J, Draper J D and Reibenspies J H, Inorg Chem., 1997, 36, 3648. 
15. Darensbourg D J, Draper J D, Larkins D L, Frost B J and Reibenspies J H, Inorg Chem., 1998, 37, 2538.

16. Katsuki T, Coord Chem Rev., 1995, 140, 189.

17. Samsel E G, Srinivasan K and Kochi J K, J Am Chem Soc., 1985, 107, 7606.

18. Srinivasan K, Michaud P and Kochi J K, J Am Chem Soc., 1986, 108, 2309.

19. Horwitz C P, Creager S E and Murray R W, Inorg Chem., 1990, 29, 1006.

20. Rao M, Sayaji R and Hussain K, Indian J Chem., 1999, 38A, 262.

21. Vogel A I, Quantitative Inorganic Anal., 1968, 3rd Ed, 567.

22. Cotton F A and Kraihanzel C S, J Am Chem Soc., 1962, 84, 4432.

23. Datta P, Gayen P and Sinha C, Polyhedron, 2006, 25, 3435.

24. Datta P and Sinha C, Indian J Chem., 2009, 48A, 1204.

25. Datta P, Patra A K and Sinha C, Polyhedron, 2009, 28, 525.

26. Graham W A G, Inorg Chem., 1968, 7, 315.

27. Brown R A and Dobson G R, Inorg Chim Acta, 1972, 6, 65.

28. Tripathi S C and Srivastava S C, J Org Chem., 1970, 23, 193.

29. Tripathi S C, Srivastava S C, Prasad G and Mani R P, J Org Chem., 1975, 86, 229.

30. Rastogi D K and Sharma K C, J Inorg Nucl Chem., 1974, 36, 2219.

31. Agarwal R C and Narang K K, Inorg Chim Acta, 1973, 7, 651.

32. Balk R W, Stufkens D J and Oskan A, Inorg Chim Acta, 1979, 34, 267.

33. Staal L H, Stufkens D J and Terpstra A, Inorg Chim Acta, 1979, 34, 97. 


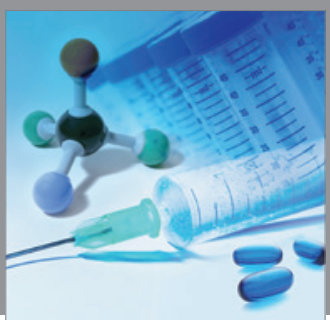

International Journal of

Medicinal Chemistry

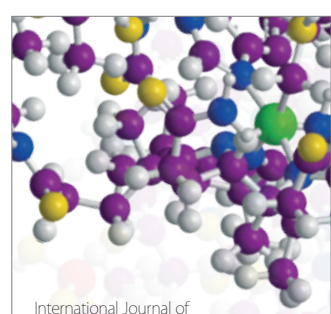

Carbohydrate Chemistry

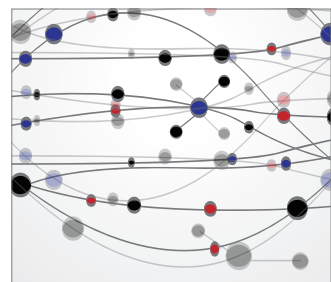

The Scientific World Journal
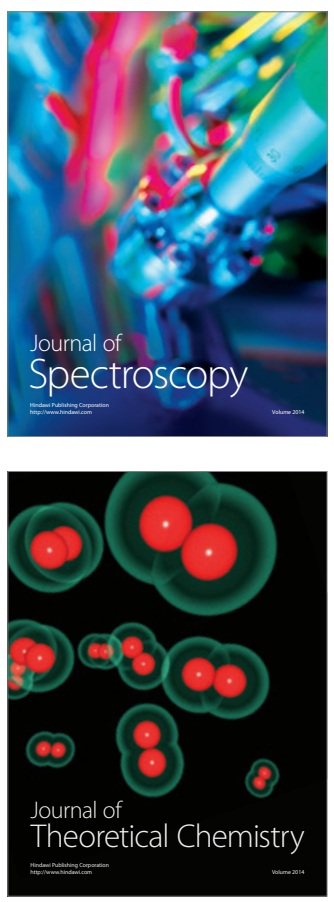
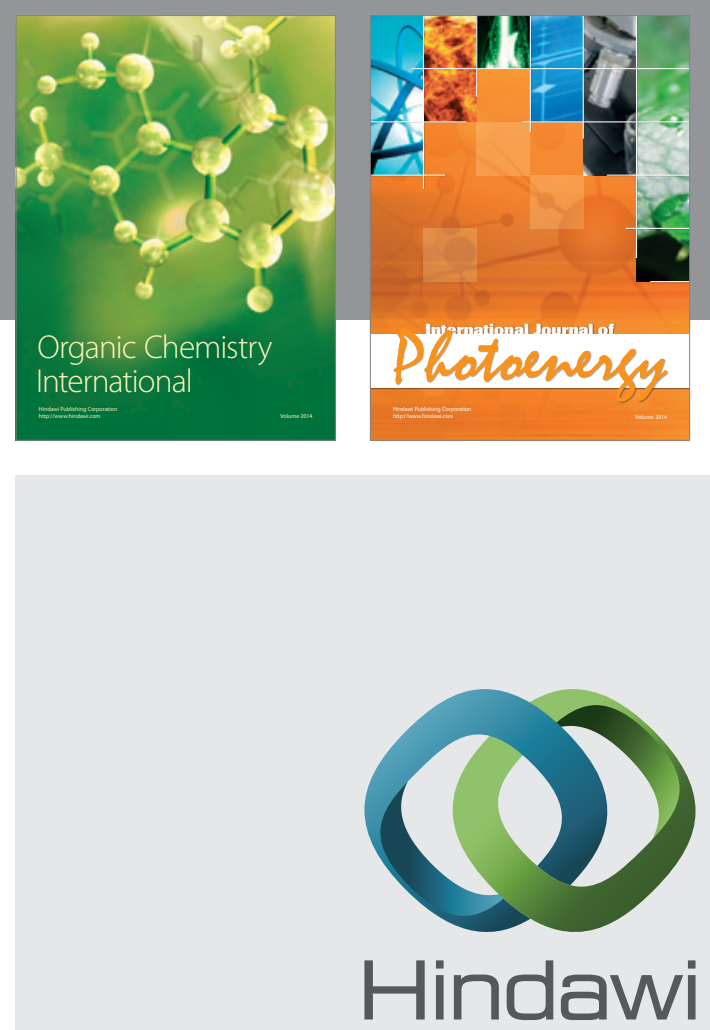

Submit your manuscripts at

http://www.hindawi.com
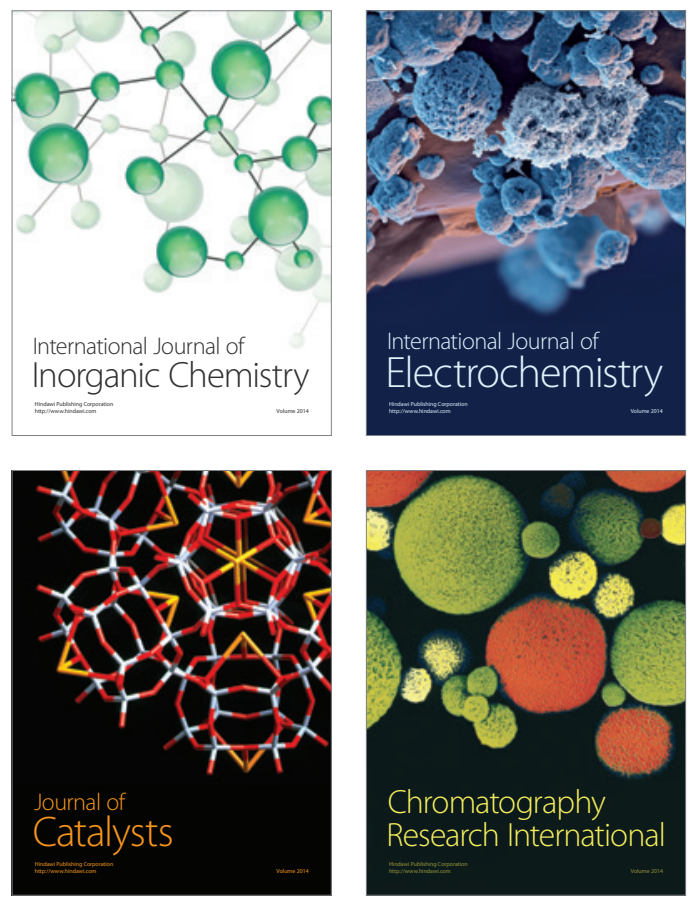
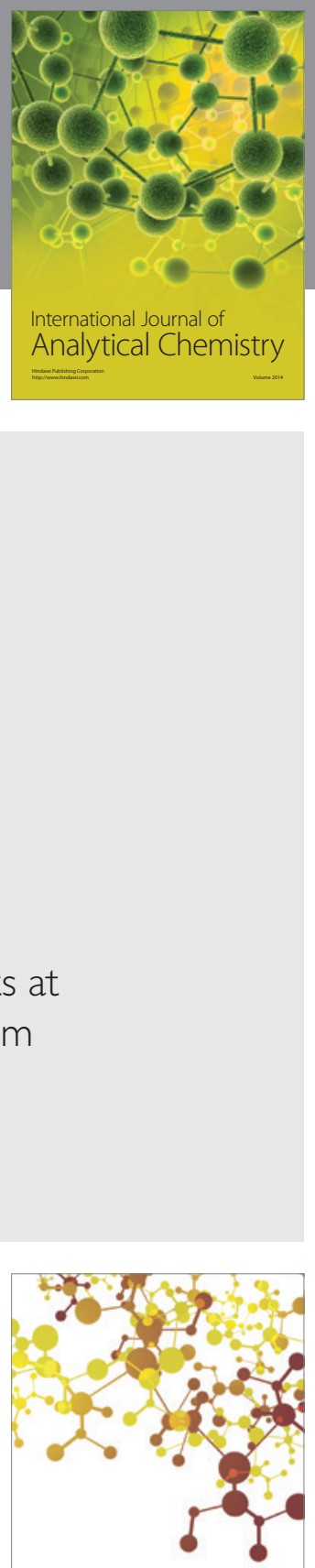

Journal of

Applied Chemistry
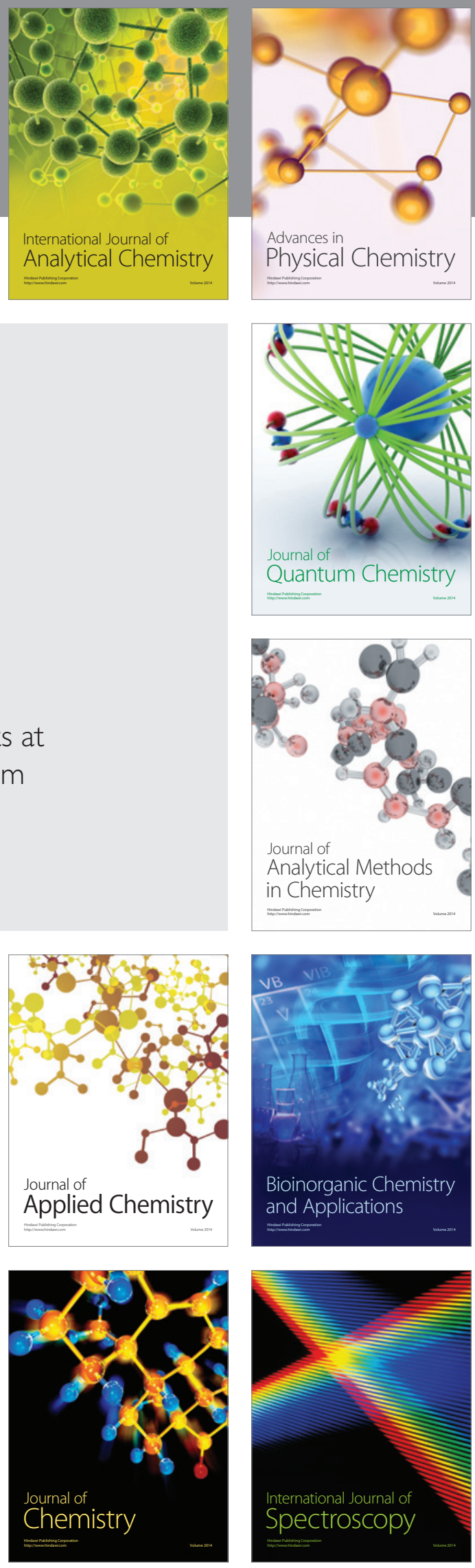